\title{
Improve Writing Performance for English Majors through the Use of Portfolios
}

\author{
Tran Thi Yen*, Phung Thi Thanh Tu** \\ Faculty of Foreign Languages Education, \\ Thai Nguyen University of Education \\ DOI: 10.29322/IJSRP.10.10.2020.p10620 \\ http://dx.doi.org/10.29322/IJSRP.10.10.2020.p10620
}

\begin{abstract}
English writing is an important skill for students; however, many English majors at universities in Vietnam have problems in writing English. Therefore, the aim of the research is to seek solutions to enhance English writing performance for English majors through the use of portfolios. The specific objectives are to draw up a procedure for creating and assessing writing portfolios, to evaluate the impacts of portfolios on English majors' writing performance, and to collect students' and teachers' feedback regarding the benefits and drawbacks of portfolios and possible solutions to enhance the effectiveness of portfolios. To conduct the study, the quasi experimental research design was used along with the survey and the expert method. Sixty students were chosen randomly; 30 of them were assigned to the experimental group (portfolio) and the others were put into the control group (non-portfolio). All of these students were required to take writing pre-tests and post-tests while only the experimental group answered a feedback questionnaire. The results show that using portfolios plays an important role in improving and enhancing English writing competence for English majors. Students' and lecturers' feedback concerning the use of portfolios in writing courses are, in general, also quite positive. Besides, the research proposes some suggestions for minimizing the shortcomings of using portfolio to enhance the potentiality of this method and make it more interesting, meaningful and effective.
\end{abstract}

Index Terms- academic writing, English majors, portfolio, writing competence, writing assessment.

\section{INTRODUCTION}

English writing is one of the essential skills for conveying knowledge gained in a particular field of study. This is an important skill for students in general and English majors in particular because it helps learners memorize, activate and reinforce the vocabulary, grammar features, structures, idioms, and ideas that they have learnt. According to Bello (1997), "writing also enhances language acquisition as learners experiment with words, sentences, and larger chunks of writing to communicate their ideas effectively and to reinforce the grammar and vocabulary they are learning in class".

Writing test results at Thai Nguyen University of Education in Vietnam show that English majors have many problems in writing an English essay. They find it difficult to open up their essays, brainstorm ideas, and employ correct words and structures in their essay. Sometimes, they also have difficulties in organizing the essay in an optimal and logical way. They need a rich source of quality material tailored to their level in order to be able to produce a good writing piece.

Training programs under the credit system have reduced the time students spend studying in classrooms, so students' awareness of self-study, the methods of self-study and the identification of self-studying contents clearly and scientifically have a huge impact on students' English performance. In addition, developing the skills of systematizing learning and reference materials is extremely important because it not only helps students become active and creative in learning but also helps English lecturers direct studentcentered teaching methods easily and effectively.

In recent years, portfolios have been used in many English writing classes as portfolios can not only document students' achievements, but also illustrate how their writing skills have developed over the years. Yang (2003) stated: "Portfolio is considered as a compilation of students' work, which documents their effort, progress and achievement in their learning, and their reflection on the materials negotiated for the portfolio". Although the utilization of portfolios to enhance English writing skill has been widely 
applied all over the world and showed many positive advantages, this method is still relatively new and less popular among many university students in Vietnam.

Looking into the context of writing classes at Thai Nguyen University of Education, to save time, many lecturers tend to assign students writing tasks and assess their performance merely based on these tasks. However, when portfolios applied in writing class, the conventional teaching style in which teachers give a writing task and students write only one daft no longer takes its dominant place. Instead, students have more opportunities to improve their writing in a series of drafts. They keep making improvements and progress in writing until their product is satisfactory.

Therefore, this study was conducted to seek solutions to enhance English writing skills for English majors through the use of portfolios. The specific objectives are to draw up a procedure for creating and assessing writing portfolios, to evaluate the impacts of portfolios on English majors' writing performance, and to collect students' and lecturers' feedback regarding the benefits and drawbacks of portfolios as well as possible solutions to enhance the effectiveness of portfolios.

\section{LITERATURE ReVIEW}

\subsection{Key concepts}

\section{Writing performance}

Writing performance can be refered to as the process of performing writing tasks (Wehmeier, 2001). Brown (2000) defined writing performance as the actual production of linguistic events. In the present study, it can be defined as the scores that the students get in the writing tasks.

\section{Writing as a process}

According to Kirby (2002), "the creative writing process permits the author to construct through a series well planned out stages, a thorough piece of writing that is both organized in its presentation and thorough in its development" (p. 1). Seow (2005) defined a writing process as an individual activity with four primary stages, namely planning, drafting, revising, and editing" (p. 315). In the present study, a writing process involves five writing stages that the students have to undergo to produce a writing piece, which are preparing, planning, drafting, revising, and editing. We added the preparation stage into the process as we could see that many of our students need this step to collect related materials to perform their writing tasks. In deed, they need to collect related writing samples, useful langugae and structures from reliable sources.

\section{The concept of portfolio}

The word portfolio derives from the Latin verb portare, which means to carry and the Latin noun foglio, which means sheets of paper. Barnard \& Deyzel (2003) defined a portfolio as a portable, systematic and purposeful collection of works selected to provide information about attitude, level of development and growth during a given period of time. It is a powerful visual tool that can demonstrate evidence of self-assessment, personal reflections, learning, growth and development and a comprehensive overview of skills."

Yang (2003) refered to portfolio as "a compilation of students' work, which documents their effort, progress and achievement in their learning, and their reflection on the materials negotiated for the portfolio". This research adopts this definition as it is suitable with the context of writing classes at our university.

\subsection{Previous research}

Many studies have been conducted to investigate the effectiveness of using portfolio on students' writing performance. For instance, Aydin (2010) carried out a case study at Balıkesir University, Turkey, with a group of 39 EFL students. The results suggested that portfolio keeping helps learners to develop not only writing skills, but also content knowledge and grammatical competence; however, some students claimed that portfolio keeping is boring, time-consuming and tiring.

A quantitative study was conducted by Song and August (2002) to compare the writing performance of two groups of advanced ESL students at Kingsborough Community College, City University of New York. Both groups had been enrolled in the course of ENG composition 2. At the end of the course, one group were assessed on the basis of portfolios as well as the writing assessment test while the other were assessed using the writing test only. The results showed that the students were twice more likely to pass the test when 
they were evaluated by portfolio than when they were required to do the writing test only. Portfolio assessment seems to be a more appropriate assessment alternative for ESL learners.

Anderson, Mallo, Nee, and Wear (2003) conducted an action research to improve writing skills for first and fifth-graders. These skills involved capitalization, punctuation, word spacing, and the use of descriptive words. The participants consisted of 41 first grade pupils and 69 fifth grade pupils in a elementary school located in a Midwestern suburb. Portfolios and journal writing were selected as intervention strategies for the study. Questionnaires, checklists, rubrics, and document analysis logs were utilized to record the progress of students' writing skills. On a weekly basis, the researchers organized teacher-student conferences to discuss students' writing drafts. The research found that journal writing and portfolios were effective interventions as they showed students' growth and improvements in their writing and reflection.

Apple and Shimo (2004) investigated students' perceptions of portfolio compilation in an EFL setting in Japan. The targeted population were 61 students in two separate universities attending English writing courses. A portfolio of students' works was used as the only means of assessment, and a self report questionnaire was used to gather learners' feedback. According to the research results, the students strongly believed that portfolio creation helped them improve compositional and expressive writing ability. The study also emphasized the benefits of portfolio assessment compared with traditional testing.

It can be seen that there are many studies related to "portfolio" and the results are universal: portfolios can help students improve their writing performance. Therefore, we decided to conduct this research in the context of Thai Nguyen University of Education to build an optimal procedure for creating and assessing writing portfolios, which is suitable to our situation, and then evaluate its impact on our students' writing performance.

\section{METHODOLOGY}

\subsection{Research design}

The present study utilized the quasi experimental research design, which is the pretest-posttest nonequivalent groups to evaluate the impacts of portfolios on English majors' writing performance. The expert method was also employed for gaining comments from experts to optimize the procedure for creating and assessing writing portfolios. Finally, a survey was conducted to collect students' feedback regarding the benefits and drawbacks of portfolios and possible solutions to enhance the effectiveness of portfolios.

\subsection{Participants}

All the third-year English majors at Thai Nguyen University of Education (TNUE) are the participants of the study. The total number of participants is 60.30 of them were assigned to the experimental group (portfolio group) and coded as E1-30 while the others were put into the control group (non-portfolio group) and coded as C1-30.

All of these students were required to take a writing pre-test and post-test while only the experimental group answered a feedback questionnaire.

\subsection{Data collection instruments and procedure}

Pre-test: Prior to the experiment, the participants (both experimental and control groups) were given an English Writing Test as a pretest.

Post-test: At the end of the experiment, another English Writing test was given to the students as the post-test.

A pre-post test design requires the researcher to collect data about the students' level of writing performance before the intervention took place, and then to collect the same data after the intervention took place. In this study, the pre-post test design allows the researchers to make inferences on the impact of portfolio compilation on students' writing performance by comparing the differences between the pre-test and post-test results.

The test papers were marked analytically based on IELTS Task 2 Writing Band Descriptors (public version). Students' writing papers were assessed separately by two rators (the researcher and a senior English teacher) on each of the four criteria: Task Achievement, Coherence and Cohesion, Lexical Resource, Grammatical Range and Accuracy. Performance on each criterion was judged along nine levels of performance from 1 to 9 . The final score was the average score of the two raters. 
Expert survey questionnaire: An expert survey questionnaire was administered to collect opinions from a group of 10 experts concerning the procedures for compiling writing portfilios and the Portfolio Scoring Rubric in order for the reseachers to perfect these procedures.

\section{Writing portfolio process}

The experiment took place in one academic year with two academic writing courses. The same writing assignments of the coursebook were given to both experimental and control groups. The two groups were taught by the same teacher (the researcher). While the control group was taught in a traditional way (non-portfolio), the experimental group received the treatment (portfolio compilation).

At the beginning of each course, all the students were well informed of the learning outcomes, which are summaried in the following table.

Table 1. Outcomes of academic writing courses

\begin{tabular}{|l|l|l|}
\hline \multicolumn{1}{|c|}{ Academic year } & \multicolumn{1}{|c|}{ 2018 - 2019 } \\
\hline Semester & \multicolumn{1}{|c|}{ Semester 1 } & Semester 2 \\
\hline Course & Academic English Writing 1 & Academic English Writing 2 \\
\hline $\begin{array}{l}\text { Learning } \\
\text { outcomes }\end{array}$ & $\begin{array}{l}\text { Students are able to: } \\
\text { complex-compound sentences. } \\
+ \text { produce different kinds of paragraphs }\end{array}$ & $\begin{array}{l}\text { Students are able to produce } \\
\text { different kinds of essays }\end{array}$ \\
\hline
\end{tabular}

The portfolio group were required to show evidence of their learning process and results in the form of a portfolio. They were also guided on the steps of compiling portfolios, considerations, sources of reference materials, kinds of input information, portfoilo assessment methods, etc.

Based on our own experience in teaching writing, we drew up a procedure for compiling portfolios. After revising the procedure several times, we consulted experts, who are also senior English lecturers from some universities in Vietnam. Thanks to their valuable opinions, we could finalize a Procedure for Creating Wrting Portfolios, which involves six main stages, namely Preparing, Planning, Drafting, Revising and Editing and twenty steps as detailed in the following table.

Table 2. Procedure for Creating Wrting Portfolios

\begin{tabular}{|l|l|l|}
\hline \multirow{4}{*}{ Process } & $\begin{array}{c}\text { Step } \\
\text { No. }\end{array}$ & \\
\hline \multirow{4}{*}{ Preparing } & 1. & Collect writing samples from reliable resources \\
\cline { 2 - 3 } & 2. & Collect useful languages from reliable resources \\
\cline { 2 - 3 } & 3. & Collect tips from reliable resources \\
\hline \multirow{4}{*}{ Planning } & 4. & Make an outline \\
\cline { 2 - 4 } & 5. & Identify what to write about \\
\cline { 2 - 4 } & 6. & Consider whom to write for \\
\cline { 2 - 3 } & 7. & Generate Wh-questions about the topic \\
\cline { 2 - 3 } & 8. & Make a list of ideas on the topic \\
\cline { 2 - 3 } & 9. & Freely write down words and phrases about the topic \\
\cline { 2 - 3 } & 10. & Collect information about the topic selected before writing \\
\hline Drafting & 11. & Write a series of drafts \\
\cline { 2 - 3 } & 12. & Focus on contents and the development of ideas \\
\cline { 2 - 3 } & 13. & Ignore grammar, spelling and punctuation mistakes \\
\hline Revising & 14. & Reread the draft to see if it makes sense \\
\cline { 2 - 3 } & 15. & Revise the content of the draft \\
\hline
\end{tabular}




\begin{tabular}{|l|l|l|}
\hline \multirow{2}{*}{} & 16. & Revise the organization of ideas in the draft. \\
\cline { 2 - 3 } & 17. & Exchange the drafts with peers for suggestions and improvements \\
\cline { 2 - 3 } & 18. & Review the draft based on the teacher's comments \\
\hline \multirow{2}{*}{ Editing } & 19. & Rewrite the draft after its revision \\
\cline { 2 - 3 } & 20. & Proofread the draft for spelling, grammar and punctuation \\
\hline
\end{tabular}

The process of portfolio-based writing can be summaried in the following diagram:

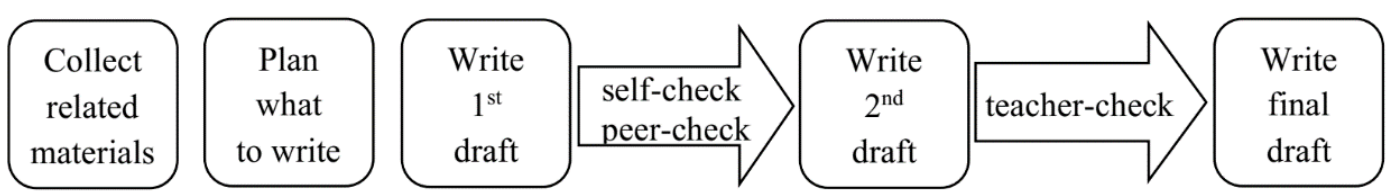

Figure 1. The process of portfolio-based writing

During the implementation of portfolios, the teacher reviewed the students' portfolio contents and provided comments and suggestions for revision on a weekly basis. No grades were given to the first and second versions; grading is delayed until the final draft of each assignment is submitted. At the end of the academic year, students' portfolios were submitted for final assessment.

\section{Student feedback questionnaire}

Firstly, the researcher required all the students to write down what they felt about writing a portfolio. Based on their feedback, the questionnaire was designed to gather the participants' feedback relating to portfolios, including such aspects as procedure/steps, benefits, disadvantages, attitudes of participants and possible solutions to enhance the effectiveness of using portfolios in writing courses. The questionnaire was designed in a mixed format, including 3-point Likert statements, close-ended questions and openended questions.

\section{Portfolio Scoring Rubric}

We have also developed a Portfolio Scoring Rubric (see Table 3) for grading the students' portfolios and perfected it after having consulting experts. Five levels of performance are signified in the rubric: A - Excellent (Score 8.5-10.0), B Good (Score 7.0-8.4), C Satisfactory (Score 5.5-6.9), D - Poor (Score 4.0-5.4), and F - Failure (Score 0.0-3.9). These levels were identified based on the grading scale of the acadenic credit system of our university, which is very familiar with the students. For each level, there are five criteria (portfolio completeness, variety of entries, use of different stages in the writing process, organization and presentation, and overall improvement).

Each level reflects students's writing performance across all the criteria. Under each level, a number of descriptors are included. Such descriptors can make each score level distinct from the others. Therefore, when assessing portfolios, teachers need to consider all the criteria and descriptors together or holistically. The total possible score is 10.0. Clear instructions concerning how to employ this rubric were also provided.

Table 3. Portfolio Scoring Rubric

\begin{tabular}{|c|c|c|}
\hline Score level & Criteria & Descriptors \\
\hline \multirow{5}{*}{$\begin{array}{c}\text { A } \\
\text { Excellent } \\
(\mathbf{8 . 5 - 1 0 . 0 )}\end{array}$} & 1. Completeness & The portfolio is complete (all the required contents are included). \\
\hline & 2. Variety of entries & The portfolio displays a wide variety of writing pieces. \\
\hline & $\begin{array}{l}\text { 3. Use of different stages } \\
\text { in the writing process }\end{array}$ & The portfolio perfectly reflect use of different stages in the writing process. \\
\hline & 4. Overall improvement & $\begin{array}{l}\text { The portfolio highly shows improvement in writing: } \\
+ \text { Writing drafts display significant changes and developments in the } \\
\text { student's use of the writing stages. } \\
\text { + Final writing products are almost free of errors and well edited. }\end{array}$ \\
\hline & $\begin{array}{l}\text { 5. Organization and } \\
\text { presentation }\end{array}$ & The contents of the portfolio are well organized and well presented. \\
\hline
\end{tabular}




\begin{tabular}{|c|c|c|}
\hline Score level & Criteria & Descriptors \\
\hline \multirow{5}{*}{$\begin{array}{c}\text { B } \\
\text { Good } \\
(\mathbf{7 . 0 - 8 . 4 )}\end{array}$} & 1. Completeness & $\begin{array}{l}\text { The portfolio is almost complete (less than } 20 \% \text { of the required contents are } \\
\text { missing). }\end{array}$ \\
\hline & 2. Variety of entries & The portfolio displays a variety of writing pieces. \\
\hline & $\begin{array}{l}\text { 3. Use of different stages } \\
\text { in the writing process }\end{array}$ & $\begin{array}{l}\text { The portfolio contents adequately reflect use of different stages in the } \\
\text { writing process. }\end{array}$ \\
\hline & 4. Overall improvement & $\begin{array}{l}\text { The portfolio shows significant improvements in writing: } \\
+ \text { Drafts show acceptable degree of changes and developments in the } \\
\text { student's use of the writing stages. } \\
\text { + Final writing products effectively communicate to the reader but contain a } \\
\text { few writing errors. }\end{array}$ \\
\hline & $\begin{array}{l}\text { 5. Organization and } \\
\text { presentation }\end{array}$ & $\begin{array}{l}\text { The contents are generally well presented and organized in appropriate } \\
\text { format. }\end{array}$ \\
\hline Score level & Criteria & Descriptors \\
\hline \multirow{5}{*}{$\begin{array}{c}\text { C } \\
\text { Satisfactory } \\
(5.5-6.9)\end{array}$} & 1. Completeness & $\begin{array}{l}\text { The portfolio is quite complete }(20 \%-40 \% \text { of the required contents are } \\
\text { missing). }\end{array}$ \\
\hline & 2. Variety of entries & The portfolio displays a collection of writing pieces. \\
\hline & $\begin{array}{l}\text { 3. Use of different stages } \\
\text { in the writing process }\end{array}$ & $\begin{array}{l}\text { The portfolio contents somewhat reflect use of the different stages of the } \\
\text { writing process. }\end{array}$ \\
\hline & 4. Overall improvement & $\begin{array}{l}\text { The portfolio shows moderate improvement in writing: } \\
\text { + Drafts display some changes and development in the student's use of the } \\
\text { writing stages. } \\
\text { + Final writing products contain several writing errors but do not hinder } \\
\text { comprehension. }\end{array}$ \\
\hline & $\begin{array}{l}\text { 5. Organization and } \\
\text { presentation }\end{array}$ & $\begin{array}{l}\text { The contents of the portfolio are organized in a satisfactory format but there } \\
\text { are some problems in presentation. }\end{array}$ \\
\hline Score level & Criteria & Descriptors \\
\hline \multirow{5}{*}{$\begin{array}{c}\text { D } \\
\text { Poor } \\
(\mathbf{4 . 0 - 5 . 4 )}\end{array}$} & 1. Completeness & $\begin{array}{l}\text { The portfolio is generally complete. }(40 \%-60 \% \text { of the required contents are } \\
\text { missing). }\end{array}$ \\
\hline & 2. Variety of entries & The portfolio displays a limited collection of writing pieces. \\
\hline & $\begin{array}{l}\text { 3. Use of different stages } \\
\text { in the writing process }\end{array}$ & $\begin{array}{l}\text { The portfolio contents poorly reflect use of different stages in the writing } \\
\text { process. }\end{array}$ \\
\hline & 4. Overall improvement & $\begin{array}{l}\text { The portfolio shows minor improvement in writing: } \\
+ \text { Drafts are insufficient to display change and development in the student } \\
\text { use of the writing processes. } \\
\text { + Final writing products contain some writing errors that interfere with } \\
\text { understanding. }\end{array}$ \\
\hline & $\begin{array}{l}\text { 5. Organization and } \\
\text { presentation }\end{array}$ & $\begin{array}{l}\text { The contents of the portfolio are poorly organized with problems in } \\
\text { presentation. }\end{array}$ \\
\hline Score level & Criteria & Descriptors \\
\hline \multirow{5}{*}{$\begin{array}{c}\text { F } \\
\text { Failure } \\
(\mathbf{0 . 0}-3.9)\end{array}$} & 1. Completeness & $\begin{array}{l}\text { The portfolio is incomplete. (more than } 60 \% \text { of the required contents are } \\
\text { missing). }\end{array}$ \\
\hline & 2. Variety of entries & The portfolio displays unrelated writing pieces. \\
\hline & $\begin{array}{l}\text { 3. Use of different stages } \\
\text { in the writing process }\end{array}$ & $\begin{array}{l}\text { The portfolio contents do not reflect use of different stages in the writing } \\
\text { process. }\end{array}$ \\
\hline & 4. Overall improvement & $\begin{array}{l}\text { The portfolio shows little improvement in writing: } \\
+ \text { Drafts are not present. } \\
+ \text { Final writing products contain numerous errors that hinder } \\
\text { comprehension. }\end{array}$ \\
\hline & $\begin{array}{l}\text { 5. Organization and } \\
\text { presentation }\end{array}$ & The components of the portfolio are organized and presented poorly. \\
\hline
\end{tabular}


Two gaders participated in grading the portfolios to eliminate the elements of bias in assessment. Each rator read and marked the students' portfolios independently using the rubric, and then the average of the two rators' scores was calculated to assign a final score.

\subsection{Data Analysis}

The quantitative analysis of data was conducted to assess the effect of the portfolio compilation on the students' writing performance. Collected data were processed manually.

\section{RESEARCH RESULTS ANALYSIS AND DISCUSSION}

\subsection{The impacts of portfolios on students' writing performance}

In order to evaluate the impacts of creating portfolios on students' writing performance, we compared the portfolio group with the non-portfolio group in terms of their writing scores. The following chart illustrates the scores in the writing pre-test and post-test gained by students in both groups.

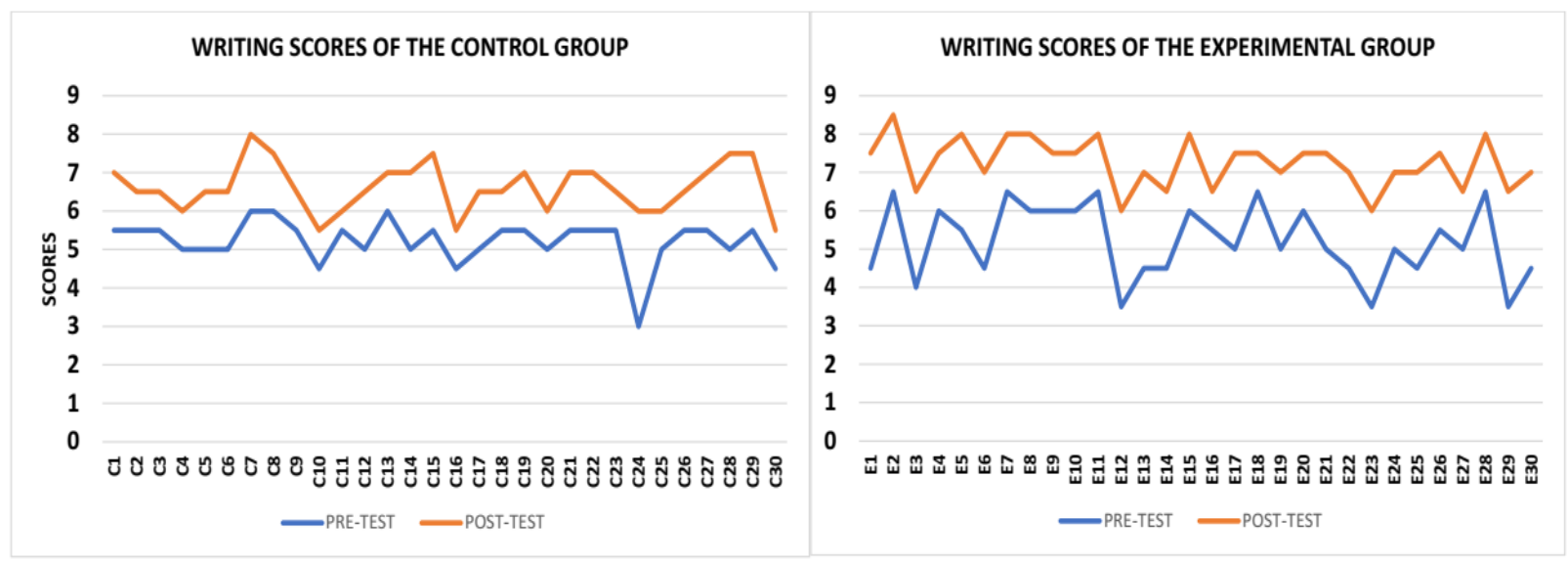

Figure 2. Writing test scores of students

It can be clearly seen that the gap between the pre-test scores and the post-test scores of the experimental group (portfolio) is significantly bigger than that of the control group (non-portfolio). In details, the pre-test socres of both groups are relatively low, primarily ranging from 4 to 6; some students even got mark 3 or 3.5. However, after taking two Academic English Writing Course, their writing performance has improved remarkably. It is visible that the post-test scores gained by the portfolio groups are mainly in the range of 7 to 8 . By contrast, the post-test socres of the non-portfolio group are mainly in the range of 6 to 7 .

For a more detailed analysis, the average scores of students are caculated and revealed in the chart below:

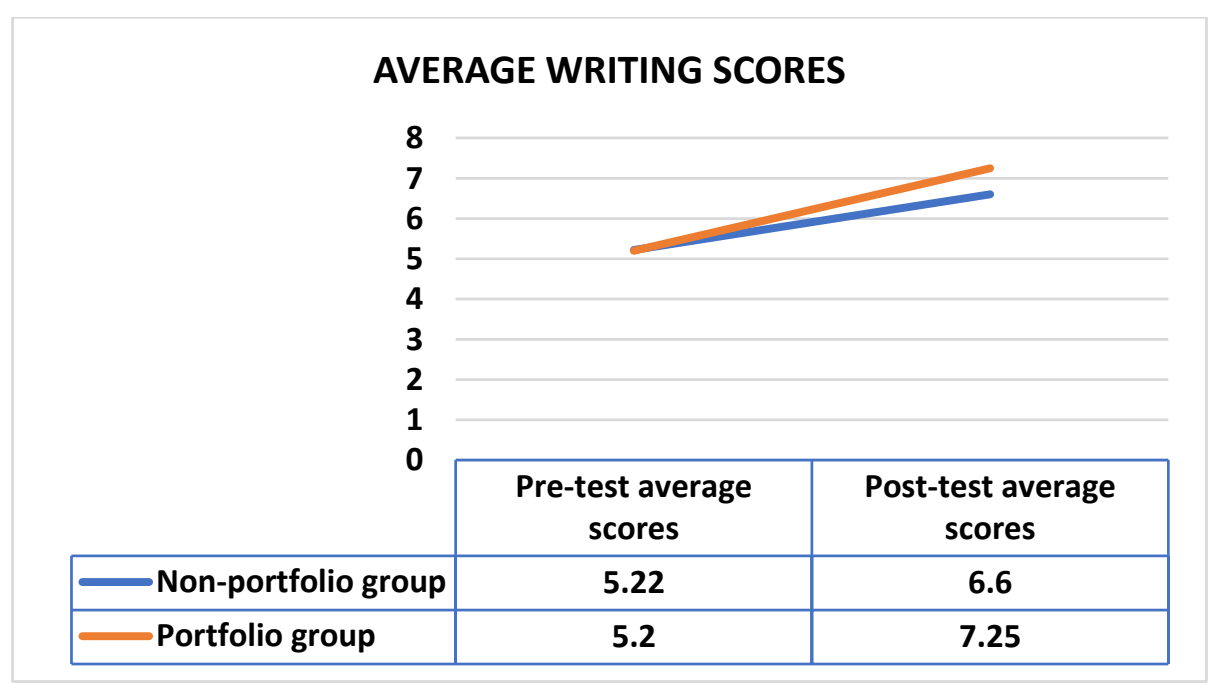

Figure 3. Average writing scores of students 
It can be seen that all of the students made a gradual improvement in academic writing performance. It is also noticeable that there is a big difference between pre-test scores and post-test scores of the 30 participants in the experimental group while there is a smaller gap between pre-test scores and post-test scores of the 30 students in the control group.

To be specific, the average writing score of the experimental and control group in the pre-test is 5.20 and 5.22 respectively. In other words, both groups' level of writing proficiency is almost similar. However, after an academic year, in the post-test the average score of the control group is much lower than that of the experimental group. Actually, the average post-test score is 6.60 for the nonportfolio group and 7.25 for the portfolio group. This indicates a big difference of 0.65 points between the two goups. Therefore, it can be concluded that creating portfolios has a positive effect on learners' writing performance.

\subsection{Results of grading student's portfolios}

To gain more information on the progress of the students in the portfolio group regarding their writing performance, we also analysed the results of grading the portfolios created by the students as can be seen in Figure 3. To grade these portfolios, we utilized the Portfolio Scoring Rubric.

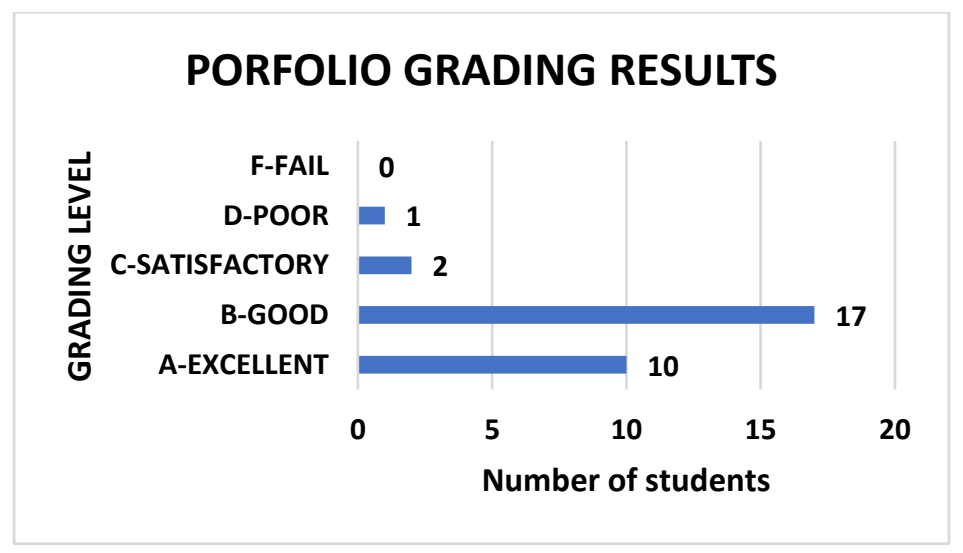

Figure 3. Results of grading student's portfolios

The figure indicates that one third of the students in the portfolio group got Grade A-Excellent for their Portfolio and more than half got Grade B-Good. Only 2 students received Grade C-Satisfactory, only one students got Grade D-Poor, and none of the portfolios was graded F-Fail.

While marking the students' portfolios, we noted that their writing performace has improved significantly over time in terms of vocabulary, grammar, spelling, punctuation and organization. Regarding vocabulary, students showed how their vocabulary increased in their portfolios as a result of the process of searching information, reading, and writing the drafts. Relating to grammar, we could see that most of the students made grammatical mistakes on the first draft, but after receiving peer check and teacher's correction, they recognized the mistakes and corrected them on the final writing product. Coming to the organization of the writing pieces, we compared the writing drafts and saw that students made a lot of progress in organizing the appearance and structure for their essays. Finally, the researchers noted that the experimental group could manipulate the writing steps in performing the writing task effectively. They did not jump into the writing stage directly but step by step prepared related materials, made a plan, drew up an outline, wrote some drafts, made revision before editing their final version. Gradually, the students became more organized and methodical when writing.

From all the analysis above, it can be noticed that when creating writing portfolios, students were given opportunities to prepare materials, develop ideas, write drafts, revise, and even edit their own writing. Therefore, the quality of their writing increased.

\subsection{Students' feedback on portfolios}

The results of the feedback questionnaires for students show that most of the students are interested in learning English writing through compiling portfolios. They would like to use portfolios not only to learn English writing but also to improve other aspects in learning the English language. 
Thirty students, who had finished compiling their writing portfolio, completed the questionnaire, which was designed basing on their notes of feelings about portfolios. Table 1 summarized the students' attitude toward creating portfolios.

Table 4. Students' attitude toward portfolios

\begin{tabular}{clccc}
\hline & \multicolumn{1}{c}{ Statements } & Disagree & Undecided & Agree \\
\hline $\mathbf{1}$ & I enjoy compiling the portfolio. & 5 & 6 & $19 / 30$ \\
\hline $\mathbf{2}$ & I am motivated to learn writing through Portfolio. & 5 & 7 & $18 / 30$ \\
\hline $\mathbf{3}$ & My English writing skills have improved. & 1 & 2 & $27 / 30$ \\
\hline $\mathbf{4}$ & I am more confident in English writing & 2 & 6 & $22 / 30$ \\
\hline $\mathbf{5}$ & I feel satisfied with my portfolios. & 2 & 4 & $24 / 30$ \\
\hline $\mathbf{6}$ & I actively participate in compiling Portfolio. & 4 & 3 & $23 / 30$ \\
\hline $\mathbf{7}$ & I am familiar with compiling portfolios. & 4 & 6 & $20 / 30$ \\
\hline $\mathbf{8}$ & It is very useful for me to review my friends' portfolios. & 3 & 4 & $23 / 30$ \\
\hline $\mathbf{9}$ & Compiling the portfolio is not a stressful process. & 2 & 5 & $23 / 30$ \\
\hline $\mathbf{1 0}$ & The portfolio is a useful self-study learning tool. & 2 & 3 & $25 / 30$ \\
\hline $\mathbf{1 1}$ & Portfolios should be applied widely. & 0 & 5 & $25 / 30$ \\
\hline Total $=\sum$ & $\mathbf{3 0}$ & $\mathbf{5 1}$ & $\mathbf{2 4 9 / 3 3 0}$ \\
\hline Percentage & $\mathbf{1 0 \%}$ & $\mathbf{1 7 \%}$ & $\mathbf{8 3 \%}$ \\
\hline
\end{tabular}

As can be seen from the table, most of the students have positive attitudes toward Portfolios (83\%). They perceived that the portfolio had been a useful self-study learning tool (25/30), motivated them in learning English writing (18/30) and should be applied widely (25/30). Most of the participants enjoyed compiling the portfolio (19/30), appreciated that their English writing skills have improved (27/30), and they gained much more confidence in English writing (22/30).

When asked to give further opinions relating to various aspects of Portfolios, the students who took part in the research gave some other ideas as summarized below:

Table 5. The benefits of compiling Portfolios

\begin{tabular}{|l|c|}
\hline \multicolumn{1}{|c|}{ Ideas } & Frequency \\
\hline The benefits of compiling Portfolios & 3 \\
\hline - It helps me gain more knowledge about English writing. & 2 \\
\hline - It helps me arrange the contents I've learnt in order. & 4 \\
\hline - I know what I have learned and how my English writing has improved through portfolios. & 3 \\
\hline - It helps me remember all important contents of English writing before final exam. & 3 \\
\hline - I can know more about useful vocabulary and improve grammar, which helps me improve & \\
\hline - your writing skill. & 3 \\
\hline - It helps me revise important knowledge easily. & 2 \\
\hline - It helps me get and organize ideas in my essays more scientifically. & 2 \\
\hline - It helps me to save their essays during my studying English writing. & 2 \\
\hline - It helps me be aware of grammatical mistakes. & 2 \\
\hline - It helps me save time in searching for resources of reference materials. & 2 \\
\hline - It is easy for me to find the structures or sample essays. & 2 \\
\hline - It helps me understand the strategies of writing an English essay. & 1 \\
\hline - Through portfolios, I can take note of vocabulary, grammar and sample essays. & \\
\hline The dwawbacks of compiling Portfolios & \\
\hline - It wastes a lot of time collecting reference materials, then compiling, sometimes & \\
\hline & rechecking and rewriting.
\end{tabular}




\begin{tabular}{|c|c|}
\hline \multicolumn{2}{|l|}{$\begin{array}{l}\text { - Sometime, it makes me feel stressed to complete my portfolio } \\
\text { Suggested Solutions }\end{array}$} \\
\hline Suggested Solutions & \\
\hline - Students should make weekly plan clearly & 12 \\
\hline - Lecturers should check students' portfolios regularly & 14 \\
\hline $\begin{array}{l}\text { - Lecturers should suggest the ways to organize portfolios and make an outline of main } \\
\text { contents for students to include in the portfolios }\end{array}$ & 15 \\
\hline - Lecturers should set a timeline for students & 8 \\
\hline
\end{tabular}

\subsection{Experts' opinions about the use of portfolios}

The experts (English lectures) also expressed strong preference on the use of portfolios in their teaching curriculum of English writing because of the benefits that portfolios bring about.

All the experts $(n=10)$ stated that they were very interested in implementing portfolios during their writing courses, and all of them felt that the technique of using portfolios was effective. In particular, the lecturers expressed their opinions related to students' portfolios, which were summarized in the table below:

Table 6. Experts' opinions about the use of portfolios

\begin{tabular}{|c|c|}
\hline Ideas & Frequency \\
\hline \multicolumn{2}{|l|}{ Benefits of implementing portfolios } \\
\hline - Portfolios make the writing courses to be more student-centered & 2 \\
\hline - Portfolios help lecturers get more detailed feedback about daily lectures & 2 \\
\hline - Portfolios allow one-to-one interaction between the lecturer and the student & 4 \\
\hline - Portfolios encourage the emergence of a more democratic environment & 4 \\
\hline - Portfolios make learning outcomes more transparent & 2 \\
\hline - Portfolios draw on students' strengths rather than focusing on their weaknesses & 3 \\
\hline - Portfolios promote individualized learning & 5 \\
\hline - Portfolios make students more active in learning & 2 \\
\hline - Portfolios regulate the habit of studying & 2 \\
\hline - Portfolios make students take responsibility of their own learning & 4 \\
\hline - Portfolios help eliminate testing anxiety & 4 \\
\hline - Portfolios encourage students to demonstrate their individual differences & 2 \\
\hline \multicolumn{2}{|l|}{ Drawbacks of implementing portfolios } \\
\hline - It is difficult to grade and assess students' portfolios. & 3 \\
\hline - Compiling portfolios takes students a lot of time and effort. & 2 \\
\hline - Monitoring students' portfolio compiling process takes lecturers a lot of time and effort. & 2 \\
\hline \multicolumn{2}{|l|}{ Suggested Solutions } \\
\hline $\begin{array}{l}\text { - Teaching writing should take place in a nicely decorated room where each student can have a } \\
\text { nice portfolio box. }\end{array}$ & 2 \\
\hline $\begin{array}{l}\text { - Clear instruction, procedures, requirements, and marking criteria should be provided on the first } \\
\text { day of the course. }\end{array}$ & 2 \\
\hline - Lecturers should make portfolios become a compulsory part of the English writing course. & 3 \\
\hline
\end{tabular}

On the whole, the results of the survey questionnaires show that most of the students and lecturers had a favourable opinion about the use of portfolios in writing courses. There are some disadvantages of implementing portfolios; however, they are outweighed by the numourous benefits and they can be partly overcome by the possible solutions as recommended above. 


\section{CONCLUSION}

The present study has shown that despite recent changes in teaching English writing, portfolios plays an important role in improving and enhancing English writing performance for English majors. Comparing to the non-portfolio class, the portfolio class has made much more significant progress in their writing performance in all aspects of vocabulary, grammar, idea development and organization. The students in the portfolio group have become more matured and organized writing process as a result of experiencing the different stages of the writing process from collectting relevant materials, making an outline, writing several drafts, making revisions to making editions so as to produce the final version.

In addition, most of the English lecturers and majors have a positive attitude toward Portfolios, and they listed many benefits which portfolios implementation brings about for not only the students, but also for the lecturers and the curriculum itself.

Besides the benefits, some problems related to portfolios implementation have also been identified and investigated. The biggest problems involve organization, time management and assessment.

To solve these problems, the participants proposed some solutions. For example, students should make weekly plan clearly and make an outline for the draft before compiling Portfolios; lecturers who teach English writing should suggest the ways for students to organize their portfolios logically, help students make an outline of main contents for their portfolio, set a timeline for students and check students' portfolios regularly.

With all of these benefits of utilizing portfolios as investigated during the two writing courses at Thai Nguyen University of Education, the researchers highly recommend that portfolios should be made an integral part of not only writing courses but also other subjects.

\section{REFERENCES}

[1] Anderson, D., Mallo, A., Nee, K., \& Wear, M. (2003). Improving writing skills in the elementary classroom. (Report No.CS 512313). Master of Arts Research Project, Saint Xavier University and SkyLight Professional Development Field-Based Master's Program. (ERIC Document Reproduction Service No. ED 479118).

[2] Apple, M., \& Shimo, E. (2004). Learners to teacher: portfolios, please! Perceptions of portfolio assessment in EFL classroom. Proceedings of JALT pan-SIG Conference. Tokyo Keizai University, 53-58.

[3] Aydin, S. (2010). A qualitative research on portfolio keeping in English as a foreign language writing. The Qualitative Report, 15(3), pp. 475 - 488.

[4] Barnard, S.E. \&amp; Deyzel, L. (2003). Career portfolio- the $21^{\text {st }}$ century career management tool. South Africa: University of South Africa.

[5] Bello, T. (1997, June). Improving ESL Learners' Writing Skills. Adjunct ERIC Clearinghouse for ESL Literacy Education Washington DC: National Clearinghouse for ESL Literacy Education Washington DC.

[6] Brown, H.D. (2000). Principles of language learning and teaching (4th ed.). New York: Longman, Addison Westley Inc.

[7] Kirby, A. (2002). Creative writing process. Retrieved April, 27, 2005, from http://www. nzcal .com/ hp/ adk/ index. Php

[8] Seow, A. (2005). The writing process and process writing. In J. C Richards, \& W.A. Renandya (Eds.), Methodology in language teaching: An anthology of current practice (5th ed., pp.315-320). Cambridge: Cambridge University Press.

[9] Song, B., \& August, B. (2002). Using portfolios to assess the writing of ESL students: A powerful alternative [Abstract]. Journal of Second Language Writing, 11 (1), 49 - 72.

[10] Wehmeier, S. (Ed.). (2001). Oxford advanced learner's dictionary of current English (6th ed.). Oxford: Oxford University press.

[11] Yang, N.D. (2003). Integrating portfolios into learning strategy-base instruction for EFL college students. Education Full Text (Wilson). IRAL, 41(4), pp. 293 - 317. 


\section{AUTHORS}

First Author - Tran Thi Yen, English lecturer, Faculty of Foreign Languages Education, Thai Nguyen University of Education, email: yentt@tnue.edu.vn

Second Author - Phung Thi Thanh Tu, English lecturer, Faculty of Foreign Languages Education, Thai Nguyen University of Education, email: tuptt@tnue.edu.vn

Correspondence Author - Tran Thi Yen, English lecturer, Faculty of Foreign Languages Education, Thai Nguyen University of Education, email: yentt@tnue.edu.vn, Mobile phone: +84979697224. 